Insignia Journal of International Relations

Vol. 7, No. 2, November 2020, 138-153

P-ISSN: 2089-1962; E-ISSN: 2597-9868

\title{
Indonesia's Cultural Diplomacy in the Conduct of Indonesian Language for Foreigners Programme in Thailand (2014-2019)
}

\author{
Inova Collins \\ School of International Relations, President University \\ Email: inovacollins14@gmail.com \\ Isyana Adriani \\ School of International Relations, President University \\ Email: isyana.adriani@president.ac.id \\ Muhammad Sigit Andhi Rahman \\ School of International Relations, President University \\ Email: andhi.rahman@president.ac.id
}

\begin{abstract}
This article examines the implementation of Indonesian Language for Foreigners Programme (Bahasa Indonesia bagi Penutur Asing or BIPA) in Thailand. On the basis of Law No.24 of 2009 Article 44, the Government of Indonesia has a task of developing the role of the Indonesian language at the international stage. This effort has attained momentum recently with the establishment of the ASEAN Economic Community (AEC), where ASEAN citizens including Thais are encouraged to have any foreign language skills. Thailand is one of the gateways to Southeast Asia. Many businesses and tourists are coming to Thailand first and then continuing to other Southeast Asian countries. This condition encourages Thai people to learn foreign languages, including the Indonesian language. This article utilises a qualitative approach, particularly interview and observation as a data collection method, and uses the concept of cultural diplomacy as the theoretical framework. It examines the content of BIPA books, BIPA's activities, the classroom learning process, and alumni's feedback towards the programme. The research findings show the high effectiveness of BIPA in Thailand. In addition to that, BIPA becomes a means of cultural diplomacy for Indonesia, the Indonesian language and culture in BIPA serve as tools in sparking Thai people's interest in Indonesia. Thereupon, it supports the government of Indonesia's effort in meeting the mandate of the Indonesian language internationalisation.
\end{abstract}

Keywords: BIPA, Cultural Diplomacy, Indonesia, Internationalisation of Indonesian Language, Thailand

\begin{abstract}
Abstrak
Naskah ini meneliti pelaksanaan program pengajaran 'Bahasa Indonesia bagi Penutur Asing' (BIPA) dalam proses internasionalisasi bahasa Indonesia di Thailand. Berdasarkan Undang-undang No. 24 tahun 2009 Pasal 44, pemerintah Indonesia memiliki tugas untuk mengembangkan peran bahasa Indonesia di panggung internasional. Upaya pemerintah Indonesia ini telah mendapatkan momentum baru-baru ini dengan ditetapkannya Masyarakat Ekonomi ASEAN (MEA). MEA mendorong warga negara ASEAN termasuk warga Thailand untuk memiliki kemampuan berbahasa asing. Thailand adalah salah satu pintu gerbang penting ke Asia Tenggara. Para pebisnis dan wisatawan datang ke Thailand dahulu dan kemudian melanjutkan ke negara Asia Tenggara lainnya. Kondisi ini mendorong orang Thailand untuk belajar bahasa asing, termasuk bahasa Indonesia. Penelitian ini menggunakan metode pendekatan kualitatif, terutama wawancara dan observasi sebagai metode pengumpulan data, dan menggunakan konsep diplomasi budaya sebagai kerangka teoritisnya. Naskah ini meneliti konten buku pengajaran BIPA, kegiatan-kegiatan BIPA yang menunjang pembelajaran siswa, proses pembelajaran kelas, dan umpan balik alumni terhadap program. Temuan penelitian menunjukkan tingkat efektivitas yang tinggi dalam pelaksanaan program BIPA yang diselenggarakan di Thailand. Selain itu, BIPA menjadi sarana diplomasi budaya Indonesia, bahasa dan budaya Indonesia dalam pengajaran BIPA menjadi perangkat diplomasi dalam menciptakan
\end{abstract}


ketertarikan rakyat Thailand terhadap Indonesia. Hal ini mendukung upaya pemerintah Indonesia dalam memenuhi amanat internasionalisasi Bahasa Indonesia.

Kata Kunci: BIPA, Diplomasi Budaya, Indonesia, Internasionalisasi Bahasa Indonesia, Thailand

\section{INTRODUCTION}

The Indonesian language is spoken by about 267 million people, the total of Indonesia's population in 2019, as projected by Bappenas (2018). The Indonesian language is the national language of Indonesia, where it is spoken nationally by Indonesians as stated in Law No. 24 of 2009 Article 1 No. 2 (Pusat Bahasa, 2010: 2). The importance of this national language has encouraged the Indonesian government to increase the role of the Indonesian language at the international level. Joko Widodo as the current president of Indonesia has always emphasised that culture shall not be abandoned in strengthening people to people contact. In his speech in front of dozens of national cultural figures at the National Gallery, he said "Do not keep talking about economic and political problems. We forget there is a cultural side that must be given attention" (CNN Indonesia, 2016). President Widodo puts the importance of culture in Indonesia's diplomatic strategy.

The Government of Indonesia under Pusat Perkembangan dan Diplomasi Kebahasaan (Strategy Development and Linguistic Diplomacy Board (henceforth referred to as PPSDK)) has been trying to internationalise the Indonesian language through the Indonesian Language for Foreigners Programme (Bahasa Indonesia bagi Penutur Asing (henceforth referred to as BIPA)) (Kemdikbud, 2019). Moreover, BIPA is not only an Indonesian language programme but also a cultural promotion programme (Suyitno, 2015).

Meanwhile, in 2015 the ASEAN Economic Community (AEC) was established (Tay \& Tijaja, 2017). It transforms ASEAN into one market and production base. It makes ASEAN become a hugely competitive economic region with new ways and measurement to strengthen the implementation of economic initiatives. One of them is having skilled labour and talent involved in AEC activities by improving their skills for profession. It can be done by learning a foreign language (ASEAN Secretariat, 2008).

Thus, to increase their competitiveness, the people of Southeast Asian countries have been encouraged to learn foreign languages, especially having proficiency in one more of the Southeast Asian languages. As Learning foreign language and cultural knowledge is crucial, where it brings the learners competitive benefit at work. Opportunities and personal satisfaction come to people as a result of their foreign language skills and cultural understanding, and it becomes plus point in the workplace (Grosse, 2004: 351-373). Foreign language skills are considered to provide a good advantage to the country, as many foreign firms are coming to invest locally, and also benefit people personally who learn it (Channel NewsAsia, 2015: 5).

Along with the benefit of learning a foreign language and cultural understanding, hence, Thai people look at Indonesia as a large country and the Indonesian language is an important language to be learnt (Maheswara, 2019). Thai people consider that learning the Indonesian language will open more opportunities for them in facing the competition in the AEC, especially in having competitive advantage and becoming skilled labour and talent (Rusiandi, pers. comm., 2019). At the same time, Thailand is an important country for Indonesia. Thailand is one of the main gateways of Southeast Asia. Promoting the Indonesian language to Thailand is significant in the internationalisation process, it supports Law No. 24 of 2009 Article 44. 
BIPA has been conducted since the era of President Susilo Bambang Yudhoyono (Tabloid Diplomasi, 2017). The platform of BIPA promotes Indonesian language and culture through BIPA books and communicative activities of BIPA that are integrated to day-to-day Indonesian sociocultural experience. This research analyses the BIPA implementation including the BIPA curriculum along with its communicative activities and its effectiveness in the internationalisation of the Indonesian language in Thailand through the BIPA student participation in class as well as the feedback.

Many works in cultural diplomacy lack empirical evidence such as further observation. This research is amongst the first that examines primary sources consisting of an interview with practitioners, and the students, direct observation in the classroom, and the content analysis of the programme materials. Additionally, this study contributes to the discourse of the 'internationalisation of the Indonesian language' and a broader discussion on the role of language in cultural diplomacy.

Moreover, the research findings inform us of the better strategy regarding the internationalisation of the Indonesian language. Traditionally, people are interested in a foreign language due to the already existing 'cultural power' of the country such as the interest in the Arabic language because of Islam, or people learn Japanese because of the popularity of Japanese graphic novel or manga, or Korean as recognition of Hallyu or Korean pop culture, etc. On the contrary, Indonesian culture is introduced through the statesupported programme of BIPA. This study demonstrates the government's support in introducing the Indonesian language through the BIPA programme. In addition to this, BIPA encourages to enhance the cultural values of Indonesia among foreigners. Thereby, a language can be an instrument for cultural diplomacy.

\section{Literature Review}

Power is a tool to achieve national interests so that each country will maximize all the potential by developing its national power to obtain its national interests (Prayuda \& Sundari, 2019:81-88). Besides the usage of power conventionally, Joseph Nye emphasises the importance of soft power. As an example, the United States has been helped by soft power in dealing with critical global issues that require multilateral cooperation rather than resorting to war (Nye, 2004).

Soft power is closely related to diplomatic practices, particularly public diplomacy and cultural diplomacy. Public diplomacy is a platform to achieve the national interests of a country through understanding, informing, and influencing foreign audiences. It aims to foster positive public opinion in other countries through interaction with an interest group (Djelantik, 2008). In this type of diplomacy, the actor is not only a state but also nonstate actors. Public diplomacy is an effort to construct positive public opinion, especially foreigners (Rachmawati, 2018: 145-147). Furthermore, state and non-state actors shall coordinate together to increase the bargaining value of the government in carrying out such diplomatic missions abroad (Hennida, 2009: 17-23).

Another relevant concept is cultural diplomacy. U.S. Department of State (1959, as cited in Gienow-Hecht and Donfried, 2010) defines cultural diplomacy as direct and ongoing contact amongst communities from different countries aimed at helping to form better international trust and understanding, where the use of culture as its main capital naturally provides space for wider participation. As stated by Cummings (2003, as cited in Baskoro, 2017: 41), public diplomacy correlates with cultural diplomacy in terms of involving cultural aspects among the public. The aim is to create mutual understanding. For this reason, cultural diplomacy is considered sub-public diplomacy. 
Mohammad Shoelhi (2011) explains a country can build an image of itself in the context of implementing its foreign policy including state branding by implementing cultural diplomacy. Indonesia uses culture as a diplomatic tool. This cultural diplomacy aims to give a cultural influence and direct the international attitude and opinion in favour of a country. He emphasises that cultural diplomacy can be conducted with various cultural events such as traditional instrument festivals, dance performances, food bazaars, and so on.

Furthermore, Tulus Warsito and Wahyuni Kartikasari (2007, as cited in Zahidi, 2016: 46) explain how the state seeks its national interest with the utilisation of national cultural elements. Moreover, they argue that language learning is an important tool in cultural diplomacy because language contains the culture itself. Language is a tool for cultural diplomacy and aims to promote the national identity of a nation-state (Ang, et. al., 2015: 365-381).

Eko Widianto and Sofi Aulia Rahmania (2018: 115-117) elaborate on the importance of language learning further. According to them, the BIPA programme is not only teaching Indonesian language and culture but also delivering economic and political diplomacy in its activities. The teaching material encompasses a variety of topics: tourism, culinary, and everyday life. Therefore, BIPA can be a platform to practice cultural diplomacy in achieving Indonesia's national interest.

According to a cultural diplomacy guidebook by Directorate of Heritage and Cultural Diplomacy, Directorate General of Culture (2018), the main purpose of cultural diplomacy is to influence public opinion especially the people of other countries to support a certain foreign policy. A cultural activity creates mutual understanding and public opinion. The main target of cultural diplomacy itself is public opinion, both at the national level, from a particular nation-state community, and internationally. Public opinion can influence decision-makers in the government or international organizations to improve the image of Indonesian culture and enhance the influence of Indonesian culture on the international level.

The country that has a high culture is going to have a chance to strengthen its position and power in the global arena. This significance leads Confucius Institute of China, Japan Foundation of Japan, and Goethe Institute of Germany to maximise the use of cultural diplomacy in promoting their language and culture. This is to approach public with the culture they have (Effendi, 2016: 21-28).

A language learning programme that is integrated with cultural aspects is an effective way to introduce Indonesian language and culture. Hence, students will not only master the language but alos understand the diverse Indonesian culture (Mussaif, 2017: 165-171). The conduct of BIPA plays an important role in promoting Indonesian language and culture and it assists to smooth Indonesia's diplomatic strategy.

Altogether, the BIPA programme presents a combination of soft power, public diplomacy, and cultural diplomacy in practice. The purpose is to use language (and culture) to influence Thai people to have a positive perspective on Indonesia. The conduct of BIPA is creating a mutual understanding of Indonesian culture besides promoting the language so that it can build a positive image of Indonesia. Thus, it directly leads Indonesia to achieving its national interest, aiming to promote Indonesian culture and supporting the Indonesian language at the international stage (Das, 2018: 2-23).

Hereby, this research provides empirical evidence of the utilisation of soft power within Indonesia's cultural diplomacy implemented through the conduct of the BIPA programme in Thailand. Furthermore, it supports the achievement in internationalising the 
Indonesian language proven through the primary data provided in the result and discussion part. The effectiveness of the BIPA program is examined through the student participation and feedback.

\section{Research Methods}

The author utilises qualitative research owing to the correlation with sources in gathering data that the author got, which was sourced from books, journals, magazines, social media posts, reports, internet, and other researches. Experts and students were also interviewed for data collection materials. The interviews were conducted in two different ways: direct interviews and interviews through social media (online).

A qualitative approach is a research process and understanding based on methodologies that investigate social phenomena and human problems (Creswell, 2013). As a qualitative approach based on investigating social phenomena. Hence, this journal author gave questionnaires to BIPA students regarding BIPA activities and effectiveness. There is a total of 45 BIPA students as respondents. BIPA teachers and Education and Culture staff at the Indonesian Embassy in Bangkok were also interviewed (both online and in person) to support the research argument. Mr. Awaludin Rusiandi from Education and Culture at Indonesian Embassy had a direct interview.

Moreover, three BIPA teachers were interviewed, Mr. Hamam Supriyadi, a BIPA teacher from Thammasat University, had a direct interview and the author also observed his social media posts. Ms. Rury Luberti, a teacher from Indonesian embassy in Bangkok, and also Prof. Siriporn Manuchekate from Maejo University, had a direct interview.

\section{RESULT AND DISCUSSION}

Law No. 24 of 2009 Article 44 relates to the issue of turning the Indonesian language into an international language, spoken widely in the international community. It encouraged the Indonesian government during President's Susilo Bambang Yudhoyono administration to establish PPSDK on $7^{\text {th }}$ April 2014 (Pusat Bahasa, 2010: 17-18).

PPSDK is under the Language Development and Cultivation Board, Ministry of Education and Culture. Its purpose is to rise up to the challenges of globalisation by turning Indonesian language into an international language to better support Indonesia's participation in maintaining peace and social justice in the world (Pusat Pengembangan Strategi dan Diplomasi Kebahasaan, 2015). Based on the 2015-2019 PPSDK's strategic plan, the institution commits to promoting the Indonesian language for foreigners. The strategy aims to improve national identity through the Indonesian language and the use of language as a means of improving strategic development and language diplomacy, including the BIPA programme (Pusat Pengembangan Strategi dan Diplomasi Kebahasaan, 2015).

The first strategic goal regarding BIPA is to improve the quality and quantity of material development strategies and language diplomacy. One of the indicators is the quantity of BIPA teaching materials. The second strategic goal is to improve the quality and number of BIPA students. This goal is measured by two indicators, which are through the number of BIPA students and the number of BIPA teachers overseas (Badan Pengembangan dan Pembinaan Bahasa, 2017).

\section{BIPA Curriculum}

The BIPA curriculum system refers to the Common European Framework of Reference for Languages (CEFR). CEFR is the general framework of European references for learning which includes learning, teaching, and language assessment (Cambridge Press, 2013). This framework is very beneficial for the internationalisation of the Indonesian 
language. The benefits can be explained in further detail below.

In 2014, PPSDK and BIPA activists worked together to harmonise the curriculum that was previously available using CEFR. Another advantage is that the transfer of BIPA students between institutions can be done easily because the competencies of each level A1-C2 have been standardised. The reference to CEFR also has an impact on material development and evaluation which will be relatively the same for all BIPA implementing agencies. Thus, the standardisation of BIPA learning is expected to be achieved and facilitate implementation, both domestically and abroad (Muliastuti, 2019). All the aspects in the BIPA curriculum follow the CEFR curriculum system including the teaching method, books, proficiency level, learning duration, and teachers.

Currently, the highest demand for learning the Indonesian language is coming from Thailand (Rusiandi, pers. comm., October 24, 2019). Thai people's interest in learning the Indonesian language has enhanced continuously each year.

Since 2015, there has been an increasing demand for BIPA teachers in Thailand. These teachers are later placed in institutions that run a BIPA program, such as the Indonesian Embassy, certain primary schools, middle schools, universities and cultural institutions in Thailand. Thailand is also the first country that has local teachers in BIPA (A. Rusiandi, pers. com., 2019). Amongst ASEAN countries, Thailand is the country that receives the most BIPA teachers (BIPA Kemdikbud, 2019a).

In 2016, BIPA teachers were sent to 47 BIPA institutions in various countries. There were 30 teachers sent to 17 BIPA institutions in Thailand, which collectively had 2,752 students (Republika, 2017). In Thailand, BIPA is conducted in several forms (Handoko, et al., 2019: 5-6).

First, the Indonesian language is offered as a minor course at school or university. A minor course means it is a related subject to a core subject in a major, also known as a sub-core course (Kyrie, 2019). Thammasat University, Naresuan University, and Fatoni University offer Indonesian language as a minor course in the ASEAN Studies major (APP BIPA Thailand, 2018).

Second, the Indonesian language is offered as an elective course at school and university. An elective course means a subject that is taken by a student to procure an integrated view of different subjects offered by a major (Kyrie, 2019). Mae Fah Luang University, Chiang Mai University, Burapha University, Pundit University, King Mongkut University of Technology, Ramkamhaeng University, and Maejo University offer Indonesian language as an elective course (APP BIPA Thailand, 2018).

The last form is to be a general learning programme or course that is offered by the Indonesian Embassy such as at the Indonesian Embassy in Bangkok, Thailand, and the course at a cultural institution. The programme is facilitated and coordinated by the Education and Culture Attaché of the Indonesian embassy as an effort to strengthen people to people contact (Soesilowati, 2017: 293-307).

At the Indonesian Embassy in Bangkok, the students are taught the Indonesian language in a daily conversation and basic lesson (R. Luberti, pers. comm., October 29, 2019). Indonesia's government through the Ministry of Education and Culture carries out various overseas cooperation activities.

BIPA has been conducted by institutions in Thailand, which consist of the Indonesian Embassy in Bangkok, primary schools, middle schools, high schools, and universities. According to JAGA BIPA Kemdikbud website, there are 42 registered institutions which conduct BIPA in Thailand (BIPA Kemdikbud, 2019b).

However, there are still many institutions, which are not registered yet on the website due to errors such as those pertaining to teacher recruitment system. It 
means the institution recruits the Indonesian language teacher conducted by itself (BIPA Kemdikbud, 2019a). It means the BIPA-implementing institutions recruit Indonesian language teachers by itself.

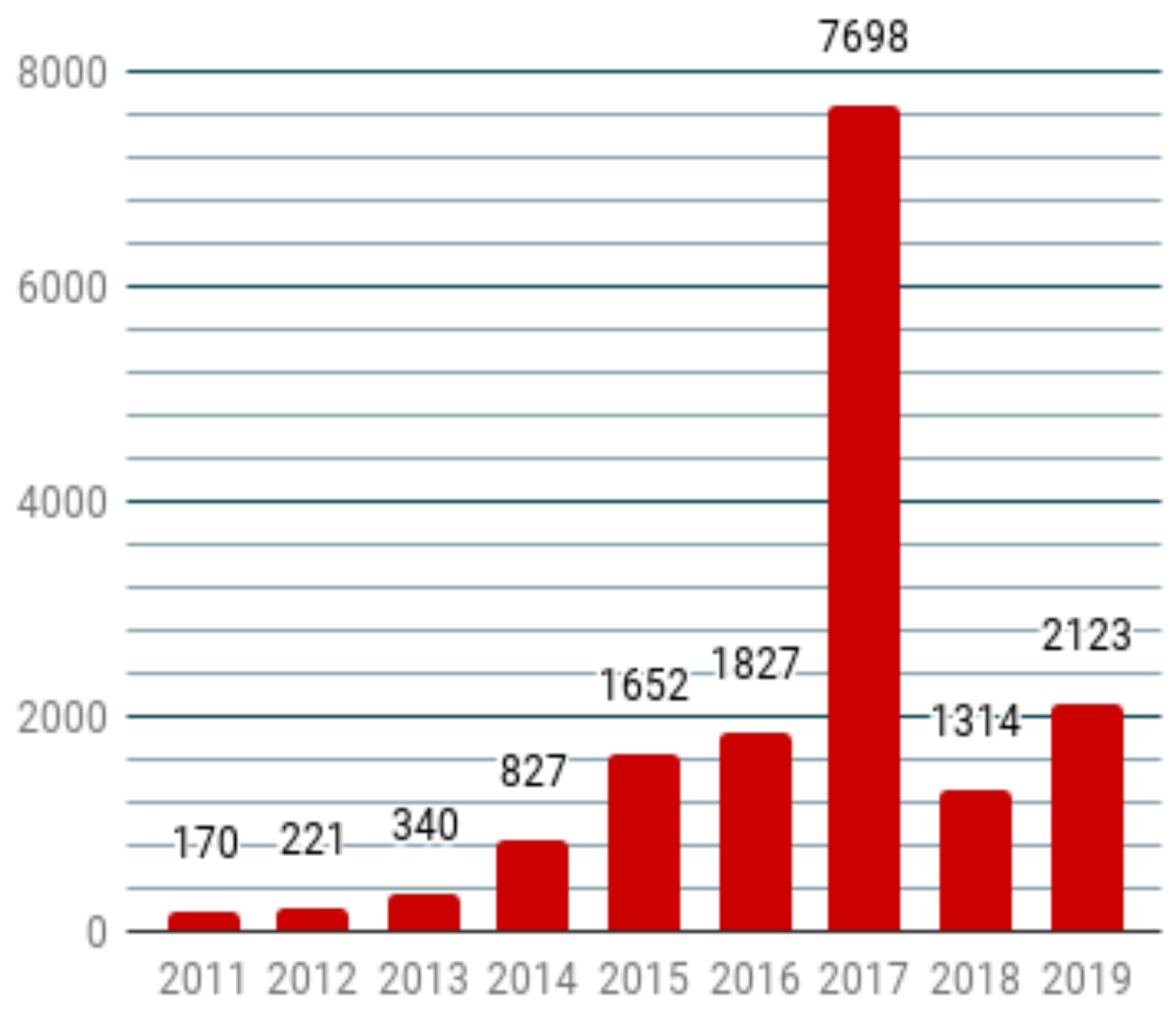

Source: APPBIPA Thailand, 2020.

Figure 1.

The Graph of the Number of BIPA Student

The bar table illustrates that the number of BIPA's student rose significantly from 2014-2017. This data was recorded by Indonesian Teachers Association in Thailand (INTAN), and the data was obtained from a few institutions that ran BIPA. In 2014, BIPA had a total of 847 students. Then BIPA reached 1,652 students in 2015. In 2016, BIPA reached a total of 1,827 students and the following year, it reached the number of 7,698 students (APP BIPA Thailand, 2020). The data proves that BIPA successfully attracted many students. It encouraged some institutions to recruit Indonesian language teachers to teach students at their institutions.
Nonetheless, based on the updated data on APP BIPA Thailand website, the number of students decreased dramatically in 2018 to 1,314 students due to some institutions' policy in regulating BIPA. According to INTAN, the decrease in the number of BIPA students in 2018 was due to several reasons. First was the institutions' policy to open and close the program. It depended on how an institution decided to support its ASEAN Languages major or any major that might need Indonesian language skills. The second reason was the limited number of teachers that could teach the Indonesian language. The third reason was that the Indonesian 
language and culture promotion through BIPA was not considered a priority at some universities in Thailand. The fourth reason was the clashing schedules of the students. Sometimes they could not attend BIPA classes because they had to attend other classes. These problems should be anticipated to overcome BIPA's problems in the future (APP BIPA Thailand, 2020).

In contrast, the number of BIPA students in 2019 increased constantly from the previous year, reaching 2,123 students (Ibid). An increase of the student numbers in 2019 from the dramatic fall in 2018 was due to some efforts. First of all, some institutions reopen BIPA as one of the subjects and the BIPA activities tend to develop significantly that support BIPA students' needs in learning. Thus, many students enrol the programme. In addition, the solid solidarity of BIPA teachers in maintaining the programme, and the student numbers gradually increases. The students are more enthusiastic right away to follow the program (Supriyadi, pers. comm., 2020). Those that approach students' attention to enrol it.

The government of Indonesia has sent BIPA teachers to many countries including Thailand. In fact, Thailand receives the biggest amount of BIPA teachers from PPSDK as there are 42 institutions that run BIPA in Thailand, as registered on the JAGA BIPA website. However, there are only 24 institutions to be facilitated by the Language Development and Cultivation Board (Badan Pengembangan dan Pembinaan Bahasa) in sending the BIPA teacher assignment (BIPA Kemdikbud, 2019b). This does not mean there are not enough BIPA teachers. Some institutions recruit their own BIPA teachers (Rusiandi, pers. comm., 2019).

BIPA books were launched in 2015, named "Sahabatku Indonesia" and published in six volumes by PPSDK. "Sahabatku Indonesia" comes in basic level (A1-A2), intermediate level (B1-B2), and advanced level (C1-C2). Those books are designed based on the CEFR system and available in print and online (Muliastuti, 2019).

The books and teaching methods of BIPA has integrated with Indonesian cultural values. It provides information about Indonesian socio-cultural aspects including social classes, gender, age, social status, familial relationships, and culture (Mustakim, n.d.). In class, the students will learn to write, speak, read, listen to Indonesian language, and they also learn Indonesian culture (Manuchekate, pers. comm., 2019). In 2017, PPSDK published a teaching material book for level BIPA 1 or level A1 in several languages including for Thai. This was the Indonesian government's effort to develop the teaching material, and the book is meant to help Thai students learn Indonesian easier (BIPA Kemdikbud, 2019c).

BIPA teachers are allowed to be creative in the classroom. For example, BIPA students at Kasetsart University, Bangkok, created an Indonesian food workshop under the guidance of their teachers (Supriyadi, 2019a). Indonesian language is also introduced through Indonesian traditional dances, games, and musical instruments as well. For instance, BIPA teachers at Maejo University, Chiang Mai, used traditional games such as congkak (board game) and bekel (game of jacks) to teach students to count in Indonesian (Bipakemdikbud, 2019).

Other than that, at Thammasat University, Bangkok, BIPA students learn to play angklung (traditional Indonesian musical instrument made of bamboo) and dance the Saman dance, a traditional dance from the Aceh province. Therefore, BIPA students do not only learn the Indonesian language but Indonesian culture as well (Supriyadi, 2019b).

The other learning form is Indonesian Day. It has been annually celebrated by the BIPA at the Indonesian Embassy in Bangkok and Southeast Asian Studies program of Thammasat University. It aims to 
commemorate the diplomatic relations between both countries (Atdikbud Bangkok, 2019a). The event involves the participation of BIPA student in performing a dance, singing, reading poetry, and opening an Indonesian food booth (Atdikbud Bangkok, 2018). This event provides BIPA students an opportunity to practice what they have learnt in the class.

Not only that, the Indonesian Embassy in Bangkok and INTAN cooperate annually in holding Indonesian speech, story-telling, and debate competitions. The competitions are conducted to find candidates that will represent BIPA Thailand in Indonesian speech and story-telling competitions that are held for foreign students of Indonesian language in Jakarta by PPSDK (APPBIPA, 2018).

Last but not least, a student camp has been conducted by Thammasat University in cooperation with the Indonesian Embassy in Bangkok, where BIPA students and Indonesian students participate in social work (Supriyadi, 2019c).

This camp was created as a contribution to society, especially to the students of Srinagarindra School, Phuket, where BIPA students share knowledge about Indonesia with the students of the school (Atdikbud Bangkok, 2019b). In addition to that, Rusiandi, through an interview on October 24 2019, stated that the camp's mission was not only to create proficient speakers of Indonesian language, but also to create agents of Indonesian culture that spread their knowledge beyond the BIPA environment.

\section{BIPA Learning Process}

The survey on BIPA students' first impression on Indonesia before joining BIPA can be a minor indicator on how far BIPA activities have changed their perspective about the country. As shown in the pie chart above, $80 \%$ had a good impression of Indonesia prior to joining BIPA and $20 \%$ did not have a good impression.
Did You Have A Bad Impression When Heard about Indonesia at First Time?

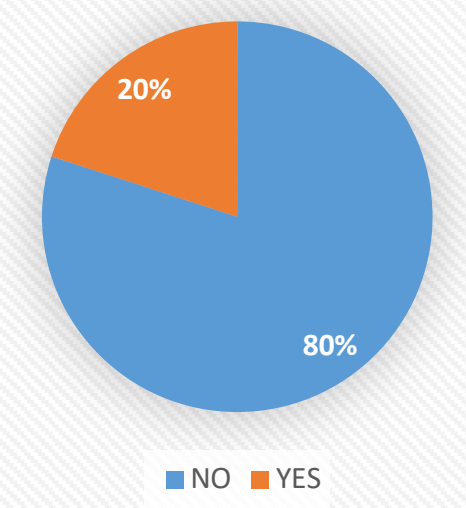

Source: Processed by Authors, 2019.

Figure 2.

Pie Chart on First Impression of Indonesia

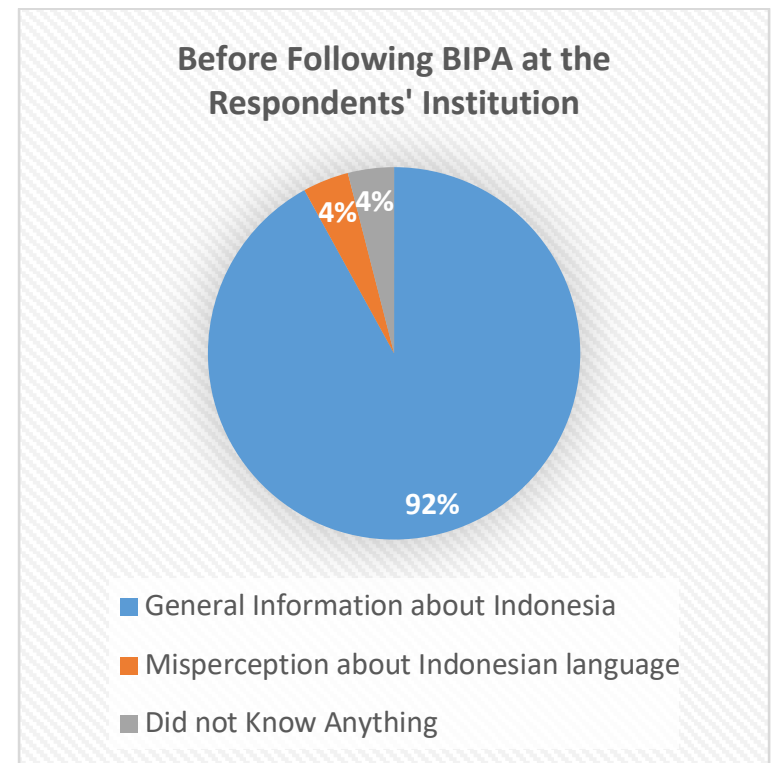

Source: Processed by Authors, 2019.

Figure 3.

Pie Chart on BIPA Students' Knowledge of Indonesia before Joining BIPA

A further research shows that $92 \%$ of the respondents know general information about Indonesia, while $4 \%$ had misconception about Indonesian and another $4 \%$ did not know anything about Indonesia before joining BIPA. Said 92\% of respondents already knew Indonesian food, currency, politics, and places of interest in the country. They also knew about 
Indonesia's ASEAN membership and that it had the biggest Muslim population in the world. These respondents gained such information from books, the internet and people around them. Some of the $92 \%$ even already knew a few basic Indonesian words.

Next, the $4 \%$ that had misconception about Indonesian language thought that the language was difficult with words that were hard to pronounce and spell and complicated grammar. They also thought that Indonesian language was the same as Malay language. The last $4 \%$ had no knowledge about Indonesia at all before enrolling in BIPA at their respective institutions.

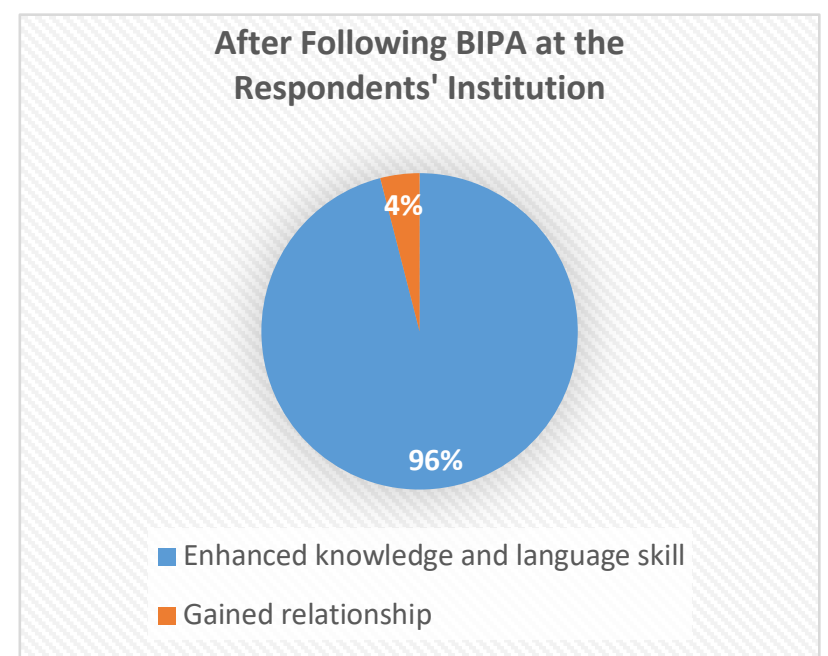

Source: Processed by Authors, 2019.

Figure 4.

Pie Chart on Respondents' experience After Enrolling in BIPA

After learning Indonesian language at BIPA, $96 \%$ of the respondents felt that they had improved their knowledge on Indonesian culture and confident about speaking Indonesian language, as shown in the pie chart above. In addition to that, $4 \%$ said that they had made Indonesian friends. Below are statements by a few of the respondents:

"Now I know more about Indonesia and I can use the Indonesian language correctly. Before joining BIPA, I only knew 'selamat datang.' I thought it was a general greeting that could be used anytime, but now I know it only means 'welcome."' (C. Naoprai, Thammasat University).

"At BIPA I learnt that Indonesian people liked to use their hands to eat, and that the majority of the population were Muslim. I also learnt that the traditional dress for women was 'kebaya' and for men 'teluk beskap.' I also can speak Indonesian confidently now." (P. Yodhakam, Maejo University)

"I have learnt the diversity of Indonesia and realised that the Indonesian language is kind of fun and not too difficult to learn." (N. Kethiangkit, International Affairs Officer).

The respondents' experience in learning Indonesian language and culture at BIPA is further enhanced by the presence of Indonesian students as interns. For example, Indonesian students at Thammasat University assist BIPA teachers in promoting Indonesian language and culture to the students. They also become friends with the students and help them practice Indonesian language.

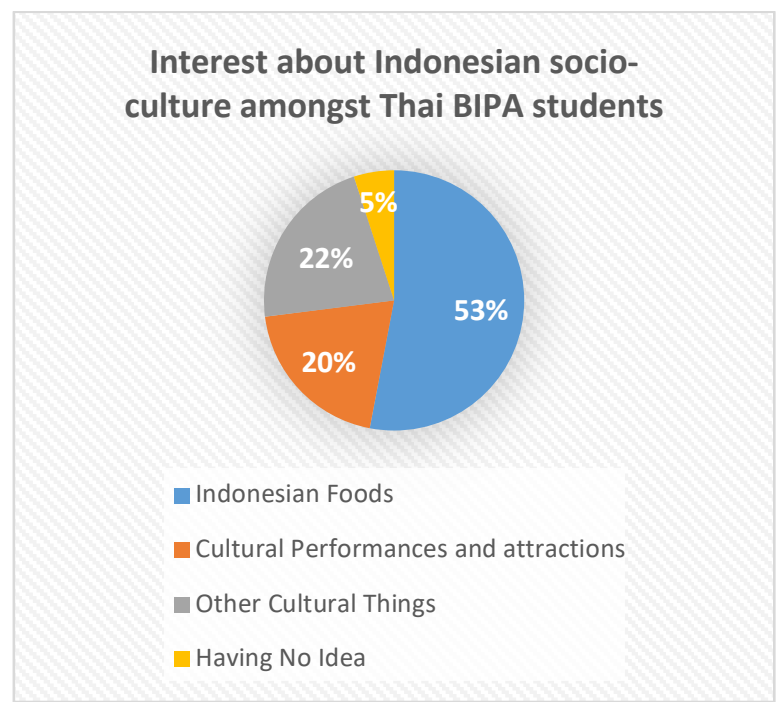

Source: Processed by Authors, 2019.

Figure 5.

Pie Chart of Interest in Indonesian SocioCulture amongst Thai BIPA Students

As shown by the pie chart above, $53 \%$ of respondents are interested in Indonesian 
food, $20 \%$ have an interest in Indonesian cultural performances and attractions, 22\% are interested in other cultural things and $5 \%$ had no idea which aspects of Indonesia they were interested in. Below are statements from the respondents about their interests:

"I like Indonesian food, especially Ayam Geprek (mashed chicken with hot chili sauce). I can cook it easily, and it is very delicious." (T. Khundilokchinda, Thammasat University).

"I like Indonesian food because it looks like Thai food in the Southern part of Thailand." (P. Suwannat, Thammasat University).

Most of the respondents like Indonesian food because according to them it is very delicious and comes in many varieties. They also said it was suitable for their taste, as Indonesian food had similar ingredients to Thai food. This fact is also helped by the fact that many of respondents are familiar with food from Southern Thailand, which is very much like Indonesian food. The majority of population in Southern Thailand are ethnic Malays, and Southern Thailand itself is near Malaysia. That also explains why Southern Thai food is similar to Indonesian food.

In the survey, $20 \%$ of respondents are interested in Indonesian cultural performances and attractions. This interest includes dance, drama and music-both traditional and modern-such as gamelan music and pop music. Several of the respondents said that listening to Indonesian songs helped them learn Indonesian language better, as stated below:

"I like Indonesian music because I love listening to music. It helps me improve my skills. I like "OK" by T2." (C. Mokthaisong, Maejo University).

Next, $22 \%$ of the respondents are interested in other cultural things such as tourist attractions that carry socio-cultural values, the multiculturalism of Indonesia, and Indonesian literature. They also like batik and are amazed that each region in Indonesia has its own types of batik. However, a few BIPA students at the Indonesian Embassy in Bangkok that made up $5 \%$ of the respondents, at the time of the survey, still had not enough knowledge of Indonesian culture to pick an interest. They also had yet to try Indonesian food.

\section{Students and Alumni's Feedback}

There were $96 \%$ of respondents who stated that the BIPA conducted at their universities had been beneficial for them. This can be proven through the statements of some respondents as follows:

"Yes, it is beneficial and effective for me. I now speak Indonesian language well and have worked at the Indonesian Embassy in Bangkok. I want to improve more to get a stronger command of the Indonesian language" (B. Petchsutee, Alumnus of Thammasat University).

"BIPA at my university, I think it is very effective and beneficial for me. It is like a door to open myself to the Indonesian world because I am quite fascinated with Indonesian language." (M. A. Musa, Chulalongkorn University).

"Yes, after learning the language at BIPA at my university, I have been able to speak, read, and write Indonesian well." (P. Y. Lueang, Maejo University).

"Yes, it benefits me a lot. I can explore Indonesia more as part of the ASEAN community. I think it is good that we exchange our culture together" (Saowanit, Government Officer).

There were also $4 \%$ of respondents (two respondents) that stated BIPA was not effective owing to its unconducive learning environment. They said that most people in the BIPA environment and outside it did not speak Indonesian, and it prevented them from continuously practicing Indonesian language. 
Is BIPA Effective and Beneficial

Program for the Respondent?

$4 \%$

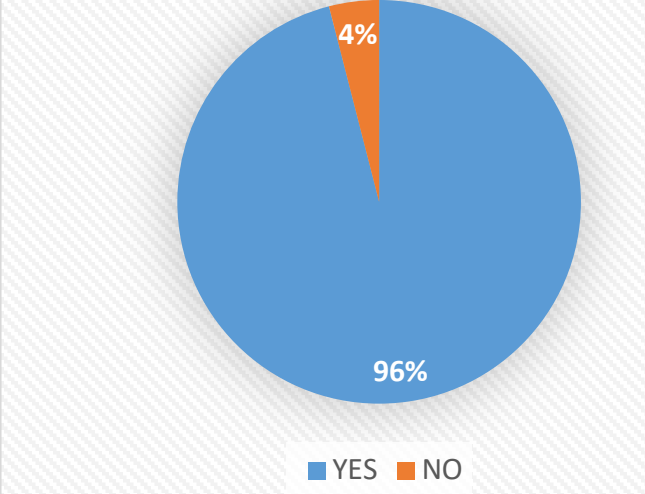

Source: Processed by Authors, 2019.

Figure 6.

Pie Chart on the Respondent Statements about BIPA's Effectiveness and Benefits

BIPA is considered an effective program, which can create successful Thai BIPA alumni who can use their Indonesian language skills at their respective work places, such as B. Petchsutee and G. Chaisukumarn (respondents from Thammasat University), and three other alumni who successfully secured employment as local staff at the Indonesian Embassy in Bangkok (H. Supriyadi, personal communication, October 12, 2019). Another BIPA student, Muhammad Amin Musa from Chulalongkorn University, won third place in an Indonesian storytelling competition and his team won the best team accolade in a debate competition in Indonesia (Badan Bahasa Kemdikbud, 2019). Other alumni have worked in professions that greatly use their Indonesian language skills such as translators, Indonesian language teachers and tour guides.

There are several benefits that Thai students acquired after following this BIPA, which are related to the improvement of their self-development in Indonesian language skills, knowledge, and interest. This effectiveness of BIPA in Thailand affects the development of Indonesia's socio-culture, education, and tourism as well. In tourism, BIPA brings an impact to Indonesia's tourism where the number of Thai tourist arrival will increase (Luberti, pers. comm., 2019).

Thai tourists have contributed to Indonesia's tourism income. As many respondents stated, there are some tourism spots that have become Thai tourists' favourite destinations. These are Borobudur Temple in Magelang, Prambanan Temple and Mount Merapi in Yogyakarta, beaches of Bali, Mount Bromo in Probolinggo, as well as cities like Jakarta and Semarang, and many more. About 33\% of respondents from $100 \%$ of respondents have been to Indonesia, which shows that Thai BIPA students have contributed to the number of Thai tourist arrivals. Not only that, the majority of respondents also have a plan to travel to Indonesia for working, and studying. This will increase Indonesia's income, especially in terms of tourism.

\section{CONCLUSION}

The conduct of BIPA in Thailand has promoted the Indonesian language and culture. Indonesian government including has indirectly participated in the sending of BIPA teachers and volunteers and guaranteeing the conduct of activities that support the learning process of BIPA students such as speech and storytelling competitions, as well as student camps. In addition to that, The Language Development and Cultivation under Indonesian government published the Book of Level 1 BIPA for Thai Speakers to promote a deeper understanding of Indonesian language and culture.

At the same time, there is a mutual need from the Thailand side, the Thai students want to learn the Indonesian language as part of their career and business development. Thai people understand the importance of learning the Indonesian language as a part of their preparation for the ASEAN Economic Community. 
BIPA program's effectiveness was measured through a survey conducted on BIPA students. The students involved in the survey did not only reveal how they felt about the learning process but also the benefits they gained in terms of selfdevelopment, increasing their Indonesian language skills and widening their knowledge on Indonesian culture.

BIPA is a means to practice Indonesia's cultural diplomacy, where Indonesian language and culture as its tool gives cultural influence to Thai BIPA students. This is the soft power that

\section{BIBLIOGRAPHY}

Ang, I., Isar, Y. R., \& Mar, P. (2015). Cultural diplomacy: Beyond the national interest? International Journal of Cultural Policy, 21(4), 365-381. DOI: https://doi.org/10.1080/10286632. 2015.1042474

APP BIPA Thailand. (2018). "Students Learn Indonesian Year 2018/2019 First Semester." Retrieved from https://appbipathailand16.weebly.c om/chart.html.

APP BIPA Thailand. (2020, February 11). "Update Mahasiswa Thailand |APP BIPA Thailand." Retrieved from https://www.appbipathailand.online /2020/02/update-mahasiswathailand.html

APPBIPA. (2018). "Annually Program: Indonesian Speech Contest." Retrieved from https://appbipathailand16.weebly.c om/history.html

ASEAN Secretariat. (2008). ASEAN economic community blueprint (978979-3496-77-1).

Atdikbud Bangkok. (2018, September 12). "Indonesian Day di Thammasat University untuk 68 Tahun Hubungan Diplomatik IndonesiaThailand." Retrieved from https://atdikbudbangkok.org/berita
Indonesia uses to promote the Indonesian language and culture. This is how the government of Indonesia has created BIPA as a cultural diplomacy strategy by providing the BIPA book and BIPA communicative activities to spark the interest of Thai people in Indonesian culture. By implementing BIPA in Thailand, the government of Indonesian has enforced Law No.24 of 2009 Article 44 on improving the role of Indonesian language on the International stage, especially in the ASEAN region.

-atdikbud/2018/09/12/indonesianday-di-thammasat-university-untuk68-tahun-hubungan-diplomatikindonesia-thailand/.

Atdikbud Bangkok. (2019a, September 26). "Indonesian Day 2019: Langkah Penguatan Kerja Sama Pendidikan Indonesia-Thailand." Retrieved from https://atdikbudbangkok.org/berita -atdikbud/2019/09/26/indonesianday-2019-langkah-penguatan-kerjasama-pendidikan-indonesiathailand/.

Atdikbud Bangkok. (2019b, November 13). "Penguatan Kerja Sama Pendidikan Indonesia-Thailand dalam Acara Kemah Persahabatan dan Pengabdian Masyarakat Mahasiswa Unnes dan Thammasat." Retrieved from

https://atdikbudbangkok.org/berita -atdikbud/2019/11/13/penguatankerja-sama-pendidikan-indonesiathailand-dalam-acara-kemahpersahabatan-dan-pengabdianmasyarakat-mahasiswa-unnes-danthammasat/.

Badan Bahasa Kemdikbud. (2019, August 16). "Bahasa Indonesia Satukan Cinta Berbagai Negara." Retrieved from https://badanbahasa.kemdikbud.go.i d/lamanbahasa/berita/2944/bahas 
a-indonesia-satukan-cinta-berbagainegara.

Badan Pengembangan dan Pembinaan Bahasa. (2017). Laporan Akuntabilitas Kinerja Instansi Pemerintah Pusat Pengembangan Strategi Dan Diplomasi Kebahasaan Tahun Anggaran 2017. Bogor: PPSDK. Bappenas. (2018).

Demografi Pembangunan. Jakarta: Badan Perencanaan Pembangunan Nasional.

Baskoro, R. M. (2017). Konseptualisasi dalam Gastro Diplomasi: Sebuah Diskusi Kontemporer dalam Hubungan Internasional. Insignia Journal of International Relations, 4(02), 35-48. DOI:10.20884/1.ins.2017.4.02.666.

BIPA Kemdikbud. (2019a). "Duta Bahasa Negara (Bakti BIPA Serba-Serbi Kiprah dan Karya Pemerhati BIPA)." Retrieved from https://bipa.kemdikbud.go.id/datad uta.php.

BIPA Kemdikbud. (2019b). "Peta Lembaga di Thailand IJAGA BIPA (Jaringan Lembaga Penyelenggara Program BIPA)." Retrieved from https://bipa.kemdikbud.go.id/jaga.p hp?show=viewnegara\&dt=173\&page $=1$.

Bipakemdikbud. (2019, November 26). "Pengalaman Mengajarkan Permainan Congkak dan Bekel kepada Pemelajar BIPA di Maejo University, Thailand" [Video File]. Retrieved from https://www.instagram.com/p/B5UL pdsHoum/?igshid=198enw4p9j540.

BIPA Kemdikbud. (2019c). "Belajar BIPA Bahan Pembelajaran BIPA: Unggahan Buku Elektronik." Retrieved from https://bipa.kemdikbud.go.id/belaja r1_det.php?js=Buku\%20Elektronik.

Cambridge Press. (2013). Introductory Guide to the Common European Framework of Reference (CEFR) for English Language
Teachers. Cambridge, U.K.: Cambride University Press.

Channel NewsAsia. (2015). Impediments for Thailand to grasp advantages from AEC. Channel NewsAsia Business Insights Thailand 2015, 5.

CNN Indonesia. (2016, August 24). "Jokowi Bahas Pola Pembangunan Kebudayaan Nasional." Retrieved from

https://www.cnnindonesia.com/nas ional/20160824081513-20153426/jokowi-bahas-polapembangunan-kebudayaan-nasional. Creswell, J. W. (2013). Qualitative inquiry and research design: Choosing among five approaches (3rd ed.). Los Angeles: SAGE Publications, Inc.

Das, k. K. (2018, October). Diplomasi dan Strategi Bahasa dan sastra: Bahasa Indonesia Sebagai Bahasa Pergaulan Internasional, 2-23. Paper presented at Kongres Bahasa Indonesia XI, Jakarta.

Directorate of Heritage and Cultural Diplomacy, Directorate General of Culture. (2018). "Pedoman Diplomasi Budaya." Kementerian Pendidikan dan Kebudayaan. Retrieved from https://kebudayaan.kemdikbud.go.i $\mathrm{d} /$ ditwdb/pedoman-diplomasibudaya/.

Djelantik, S. (2008). Diplomasi Antara teori \& praktik. Yogyakarta: Graha Ilmu.

Effendi, T. D. (2016). Bahasa Indonesia Diplomacy and Other Country Language Diplomacy Experience. Global Journal of Politics and Law Research,4(3), 21-28. DOI:10.5539/jpl.v10n2p97.

Gienow-Hecht, J. C., \& Donfried, M. C. (2010). Searching for a cultural diplomacy. New York and Oxford: Berghahn Books.

Grosse, C. U. (2004). The competitive advantage of foreign languages and cultural knowledge. The Modern Language Journal,88(3), 351373. DOI: 
https://doi.org/10.1111/j.0026-

7902.2004.00234.x.

Handoko, M. P.

Fahmi, R. N.,

Kurniawan, F. Y., $\quad$ Artating, H., \&

Sinaga, M. S. (2019). Potensi

pengembangan Bahasa Indonesia

menjadi Bahasa internasional. Jurnal

Bahasa Indonesia bagi Penutur Asing

(JBIPA), 1(1),

5-6.

DOI:10.26499/jbipa.v1i1.1693.

Hennida, C. (2009). Diplomasi publik dalam politik luar negeri.Journal Unair: Masyarakat, Kebudayaan dan Politik, 22(1), 17-23.

Kemdikbud. (2019, July 5). "Upaya Internasionalisasi Bahasa Indonesia, Pemerintah Terus Kirim Tenaga Pengajar BIPA Ke Luar Negeri." Retrieved from https://www.kemdikbud.go.id/main /blog/2019/07/upaya-

internasionalisasi-bahasa-indonesiapemerintah-terus-kirim-tenagapengajar-bipa-ke-luar-neger.

Kyrie, H. (2019, January 28). "Double major, minor, and elective courses." Retrieved from https://uwaterloo.ca/school-ofaccounting-and-

finance/blog/post/double-majorminor-and-elective-courses

Maheswara, A. (2019, July 24). "Reaksi Orang Thailand Tentang Indonesia" [Video]. Retrieved from https://www.youtube.com/watch?v $=\mathrm{Ng} 5$ egXRxce 0 .

Muliastuti, L. (2019). Bahasa Indonesia Bagi Penutur Asing: Acuan Teori dan Pendekatan Pengajaran. Jakarta: Yayasan Pustaka Obor Indonesia.

Mussaif, M. M. (2017). Keanekaragaman Budaya Menjadi basis Pembelajaran BIPA. Nusa: Jurnal Ilmu Bahasa dan Sastra, 12(4), 165-171. DOI:10.14710/nusa.12.4.164-172.

Mustakim. (n.d.). Peranan Unsur Sosial Budaya dalam Pengajaran BIPA. Jakarta: Pusat Bahasa Jakarta.
Nye, J. (2004). Soft power: The means to success in world politics. New York: PublicAffairs.

Prayuda, R., \& Sundari, R. (2019). Diplomasi dan Power: Sebuah Kajian Analisis.Journal of Diplomacy and International Studies, 2(1), 8188. DOI:

https://doi.org/10.25299/jdis.2019. vol2(01).4429.

Pusat Bahasa. (2010). “Undang-Undang Republik Indonesia Nomor 24 Tahun 2009: Bendera, Bahasa, dan Lambang Negara, Serta Lagu Kebangsaan." Retrieved from http://badanbahasa.kemdikbud.go.i d/lamanbahasa/sites/default/files/ UU_2009_24.pdf.

Pusat Pengembangan Strategi dan Diplomasi Kebahasaan. (2015). Rencana Strategis 2015-2019. Jakarta: PPSDK.

Republika. (2017, April 5). "Thailand Negara Penerima Kiriman Tenaga Pengajar BIPA Terbanyak 2016 |Republika Online." Retrieved from https://nasional.republika.co.id/beri ta/nasional/umum/17/04/05/onxy hx361-thailand-negara-penerimakiriman-tenaga-pengajar-bipaterbanyak-2016.

Shoelhi, M. (2011). Diplomasi: Praktik komunikasi internasional. Bandung: Simbiosa Rekatama Media.

Soesilowati, S. (2017). Diplomasi soft power Indonesia melalui Atase Pendidikan Dan Kebudayaan.Jurnal Global \& Strategis, 9(2), 293307. DOI:

https://doi.org/10.20473/jgs.9.2.20 15.293-308.

Supriyadi, H. (2019a, November 9). "Workshop Cooking Thai and Indonesian Food by Kasetsart and UNNES students" [Video File]. Retrieved from https://www.facebook.com/hamam.s upriyadi/videos/101576935067331 $47 / ? d=n$. 
Supriyadi, H. (2019b, March 27). "The BIPA students at Thammasat University learn to play Angklung Instrumental Music" [Video File]. Retrieved from https://www.facebook.com/hamam.s upriyadi/videos/101571043692931 $47 / ? d=n$.

Supriyadi, H. [Hamam]. (2019c, November 1). "Social service program to Srinagarindra School - Rayong Province by Indonesian classes at SEAS TU and Featured by Indonesian Embassy for the Thailand Kingdom, UNNES Semarang, and UAD Yogyakarta students." Retrieved from https://www.facebook.com/hamam.s upriyadi/posts/1015767045004314 $7 / ? \mathrm{~d}=\mathrm{n}$.

Suyitno, I. (2015, September). Pemahaman Budaya dalam Pembelajaran Bahasa Indonesia Bagi Penutur Asing (BIPA). Paper presented at Prosiding Seminar Internasional Menjadikan Bahasa Indonesia sebagai Bahasa Internasional, Malang, Indonesia.

Tabloid Diplomasi. (2017, August 15). "Bahasa Indonesia Menggeliat Di Thailand." Retrieved from https://tabloiddiplomasi.org/bahasa -indonesia-menggeliat-di-thailand/
Tay, S., \& Tijaja, J. P. (2017). Global Megatrends: Implications for the ASEAN economic community (978602-6392-67-1). ASEAN Secretariat.

Widianto, E., \& Rahmania, S. A. (2018). Economic and political diplomacy in disruption era through Indonesian for speakers of other language (BIPA) teacher assignment overseas. Proceedings of the International Conference on Science and Education and Technology 2018 (ISET 2018), 247, 115-117. DOI:10.2991/iset-18.2018.24

Zahidi, M. S. (2016). KSCC Dan Diplomasi Budaya Korea. Insignia Journal of International Relations, 3(01), 44-59. DOI:10.20884/1.ins.2016.3.01.467

\section{Interview}

Luberti, R. (2019, October 29). Personal Communication.

Manuchekate, S. (2019, October 14). Personal Communication.

Rusiandi, A. (2019, October 24). Personal Communication.

Supriyadi, H. (2019, October 12). Personal Communication.

Supriyadi, H. (2020, November

6). 